\title{
THE RELATION OF OCCUPATIONAL SAFETY MOTIVATION AND AGE, YEARS OF SERVICE AND PROFESSIONAL QUALIFICATIONS OF EMPLOYEES
}

UDC 331.101.3:331.125]:378

\author{
Tomislav Rakić1, Snežana Živković ${ }^{2}$ \\ ${ }^{1}$ TommyR Corptex d.o.o. Leskovac, Serbia \\ ${ }^{2}$ Faculty of Occupational Safety in Niš, University of Niš, Serbia
}

\begin{abstract}
Autonomous occupational safety motivation can be a result of outer and inner reasons for applying safety measures at work. Employees with autonomous motivation behave apply safety measures at their own insticts and initiative, in line with their values and interests. As a result, the behavior of autonomously motivated employees is self-determined and therefore, it should be applied consistently.

Along with this kind of motivation, an "identified" workplace safety motivation is worth mentioning. It is typical for employees who are motivated to apply occupational safety measures because they consider that safe work environment is very important, and that acting in accordance with safety measures is just another step towards safe work environment.

The main aim of this paper is to establish potential relations between occupational safety motivation on one side, and age of the examinees, the years of service, and their professional qualifications on the other, in order to implement the results obtained, create safe work environment and, in this way, increase the productivity.
\end{abstract}

Key words: occupational safety motivation, productivity, correlation, age, years of service, professional qualifications

\section{INTRODUCTION}

Numerous definitions of motivation in literature have certain similarities in terms of individual motivation which begins with the desire to reach something specific, continues with physical action, and then mental affirmation of desire fulfillment [13]. A modern, knowledge-based organization assumes that employees should be motivated to do more than their job. In this case, there is an aspiration to achieve the highest individual motivation, and it is when the following conditions are fulfilled: when the individual believes that what he is

Received October 27, 2019 / Accepted April 15, 2020

Corresponding author: Snežana Živković

University of Niš, Faculty of Occupational Safety, Čarnojevića 10a, 18000 Niš, Serbia

E-mail: snezana.zivkovic@znrfak.ni.ac.rs 
doing will produce certain results; when the individual feels that the result is appealing and when the individual believes it is possible to achieve the desired effect [11]. For performing certain jobs, motivation can be a result of satisfaction in doing certain activities. The link between performance and rewards is an important factor in motivating employees and is considered a crucial factor in the effectiveness of the system [2]. A human is motivated and led to do certain activities by inner or intrinsic motivation. In other cases, motivation for performing certain activities can be found in outer incentives (earnings, improving the financial position etc.) in which case it is said that people are motivated by outer or extrinsic motivation. Companies that haven't developed a strategy for motivating and rewarding, have a bad working atmosphere, lack of reliability and trust, employees feel bad, and this inevitably leads to stagnation and decline [1]. Poor motivation for work, as well as job dissatisfaction, can have numerous negative effects on the organization, which have been identified in many studies, such as: increased absenteeism, low employee commitment, reduced productivity, lower team efficiency and greater employee turnover [3, 7, 14].

According to the listed above, intrinsic motivation is defined as doing some activities for its inherent satisfaction and not accomplishing some favorable outcome. This kind of motivation can be separated from extrinsic motivation, which is related to acting connected to performing activities in order to reach a certain outcome [10].

Basic forms of motivation can be projected on occupational safety motivation. Intrinsic motivation for occupational safety includes an individual's perception of the significance of resources, consultation meetings, participation and initiation in organizations and improvement of occupational safety. Extrinsic motivation can influence inner motivation, for example, when the employees have constructive and positive feedback from the management, thus creating inner motivation. A leader can support and recognize improvement among employees by creating a sense of accomplishing and being part of the organization, which can also lead to inner motivation [8]. Contrary to this, awarding in money can decrease inner motivation [4].

A worker cannot be only intrinsic motivated for occupational safety and doing assignments since no individuals can be led by intrinsic motivation exclusively. Along with this, in order to understand completely the heterogeneity and the effect of motives on employees to apply safety measures during work, it is necessary to analyze suitably and explain influences of outer factors under whose effect an extrinsic form of motivation for occupational safety appears.

Besides intrinsic and extrinsic occupational safety motivation, it is equally important to establish and make a difference between controlled and autonomous occupational safety motivation. The first form represents the sense of need i.e. necessity to apply safety measures or thinking that a person should work in a safe way, respecting prescribed occupational safety measures [6]. Because of this, safe work behavior which is an outcome of controlled motivation is a result of the fact that an employee feels forced to act like this. The pressure on an employee to act following safety norms can come from other individuals (e.g. supervisor, manager), group (e.g. an organization), society (e.g. Occupational and Health Safety Law) or an individual himself. Therefore, this kind of controlled motivation can be characterized as a pressure from the outside (outer motivation for occupational safety) or inner pressure (an introjected type of motivation) for application of occupational safety measures.

Introjected occupational safety motivation urges to apply safety measures because an employee feels forced to act in a certain way but this sense comes from inside, from an employee himself and not from another person or a group. Inner pressure for behaving 
by safety norms in most individuals is experienced as the feeling of guilt or shame [5]. For example, an employee can be motivated to wear and use his/her safety belt while working on heights, but not because he/she will be rewarded or praised for doing so, but because he/she will feel guilty and ashamed if he/she does not wear a safety belt. An employee, also, can be introjected motivated to apply occupational safety measures since self-respect is determined by being an employee who complies with safety procedures and regulations.

Autonomous occupational safety motivation can be a result of outer and inner reasons to behave safely at work. Employees with autonomous motivation behave apply safety measures at their own insticts and initiative, in line with their personal values and interests. As a result, the behavior of autonomously motivated employees depends on an individual, and therefore, it should be constantly applied.

With this type of motivation, another occupational safety motivation should be mentioned and identified being unique for employees who are motivated to participate and apply safety measures because they consider the safe work environment to be important and accept that complying safety measures is necessary to accomplish their goal - safe work environment. For example, the group of workers on a new construction site immediately start risk assessment because they consider these kinds of assessments shall provide useful guidance on how a construction site could be a safe workplace. If employees do danger assessment because they value information obtained by activity agency, their motivation is still led by outer incentives. This is due to the fact that they will perform concrete activity in order to get preferred outcome. However, with employees who established and accepted the values of outcomes, their behavior will be autonomous and self-governed.

\section{METHODOLOGY OF RESEARCH}

The subject of this study is a complex phenomenon of occupational safety motivation. Also, the paper deals with the ways of establishing the hierarchy of motives and factors which affect the employees' occupational safety motivation in domestic social and organizational conditions. The following suitable scientific-investigative methods have been used in the research:

\section{Questionnaire method}

A questionnaire was used as the main investigation method by which the investigation of the subjective attitude of the employees was done.

The instrument of the investigation was a modified scale for measuring occupational safety motivation [12], which consisted of 40 questions.

Question number 9 involved seven incentives for work (earnings, secure employment, interpersonal relations, personal needs, occupational safety, the content of work, participating in decision-making process) where the employees ranked the listed incentives numerically, using the values (1-5).

\section{Statistical methods}

The following statistical methods were used for the analysis:

- Frequency

- Percentage

- Cumulative percentage

- Rank 
- Standard deviation

- Correlation coefficient

- Paired sample T test

- Data crossing

- ABC diagram.

Statistic data processing was done by program package for statistic data analysis SPSS for Windows 19.0.

\section{The sample of investigation}

The sample of investigation consisted of 361 employees in companies 'Kontejnerski transport i generalni tereti' (KTGT) AD Bar and 'Port of Adria' AD Bar, Montenegro. The sample included different examinees from different work departments, gender, age, years of service and education [9].

The investigation was done in two parts. The first investigation was done in 'Kontejnerski transport and generalni tereti' (KTGT) Bar from 2014 to 2015.

After some changes in ownership and organizational structure, and opening of the company 'Port of Adria', the investigation was done by the same methodology in 2018 .

\section{The RESUlts AND Discussion}

Based on the collected data processed by analytical software SPSS, the following results were obtained:

\subsection{The relation between occupational safety motivation and employees' age}

\section{- KTGT Bar}

From the analysis of the relationship between occupational safety as a motivating factor for various age groups within the organization we obtained the following results:

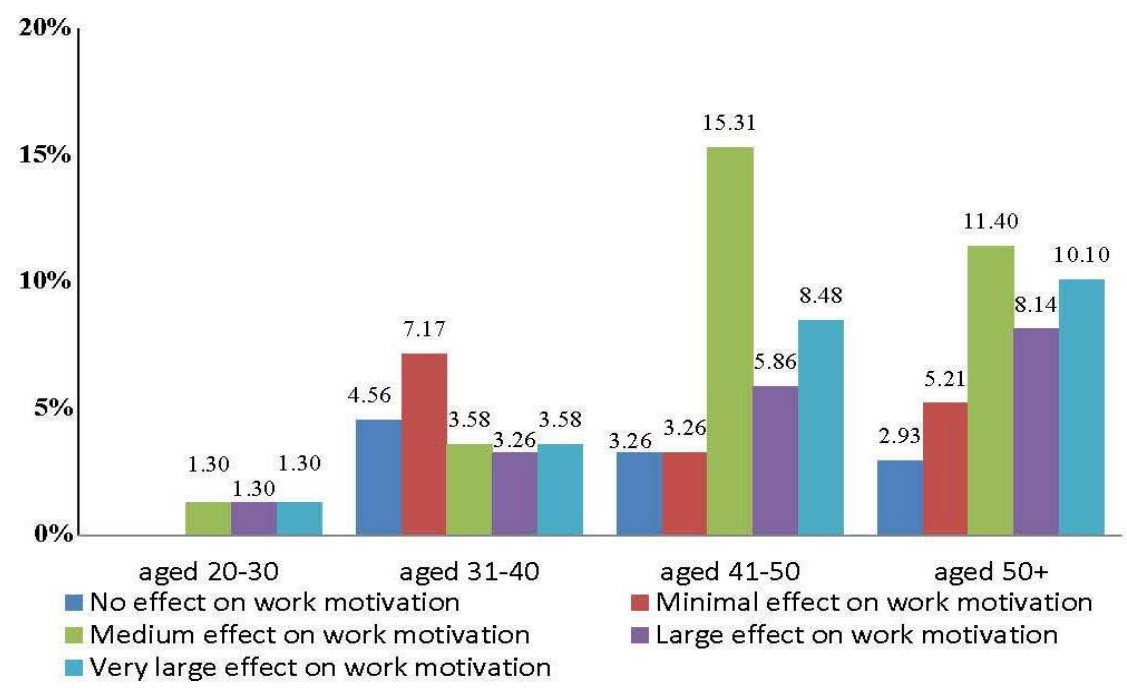

Fig. 1 The relation between motivation and age 
Based on the results shown in Figure 1, it can be seen that occupational safety motivation has the largest effect on the two oldest groups of the employees. It can be concluded that groups of the employees above 50, as well as the groups aged 41-50, realize the significance of occupational safety because during their years of service they have come across with different situations, and therefore they better recognize potential risks and see occupational safety motivation as something positive. The group of the employees aged 31-40 does not have clearly defined opinion of occupational safety, as well as the youngest group.

For this reason, it can be concluded that there is a clear difference between age groups when it comes to the age criteria of occupational safety motivation. In support of this claim, occupational safety motivation increases with age.

\section{- Port of Adria}

Similar to the previous company KTGT Bor, the analysis of the relationship between occupational safety and various age groups yielded the following results:

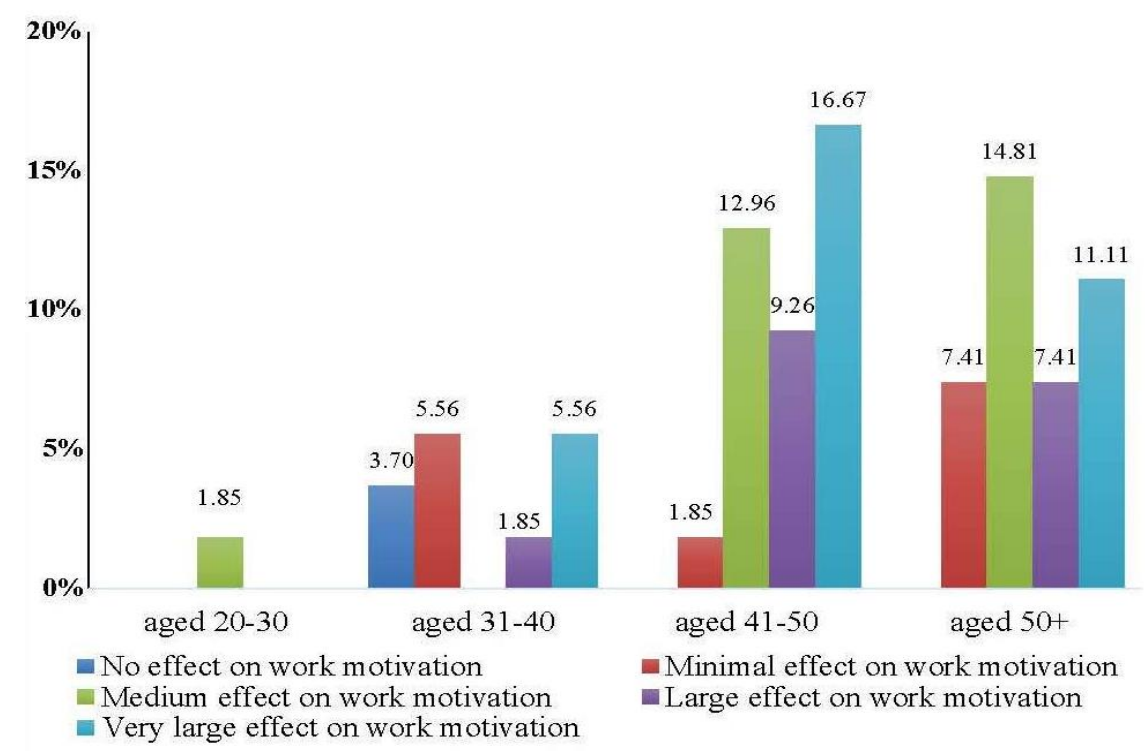

Fig. 2 The relation between motivation and age

Based on the results shown in Figure 2, it can be seen that occupational safety motivation has the largest effect on the two oldest groups of the employees. It can be concluded that groups of the employees above 50, as well as the groups aged 41-50, with the largest effect of occupational safety motivation, are conscious of the potential everyday risks, they have had negative experiences and have a positive attitude towards occupational safety. On the contrary, the younger population, aged 31-40, do not have clearly defined attitudes towards occupational safety motivation, especially in comparison to the youngest group of the examinees. 


\subsection{The relation between occupational safety motivation and years of service of the examinees}

\section{- $\mathrm{KTGT}$}

Based on the obtained results, it can be noticed that employees with more years of service have positive attitudes towards occupational safety, in comparison to the employees with fewer years of service, especially when it comes to to the population with 6-15 years of service (Figure 3).

Work experience is a crucial factor leading to the decrease in accidents, while trainings and professional competences are yet another form of employee experience and knowledge. Since employees with more years of service have more experience, they have had more training and professional competences, and as a result, they have a higher risk awareness. It is reasonable to assume that their motivation for occupational safety is significantly higher when compared to younger employees.

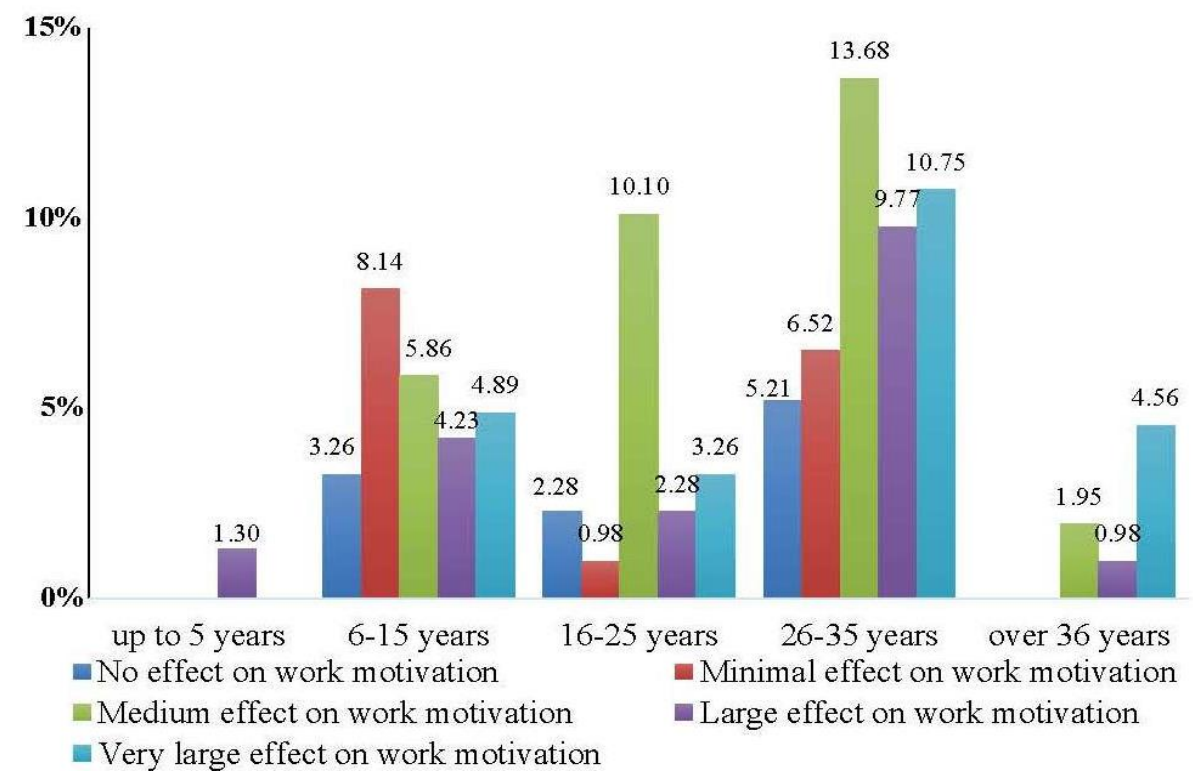

Fig. 3 The relation of motivation and years of service

\section{- Port of Adria}

Based on the obtained results, it can be noticed that the employees with longer years of service have positive attitudes towards occupational safety motivation, in comparison to the employees with shorter years of service, especially the population with 6-15 years of service (Figure 4). 


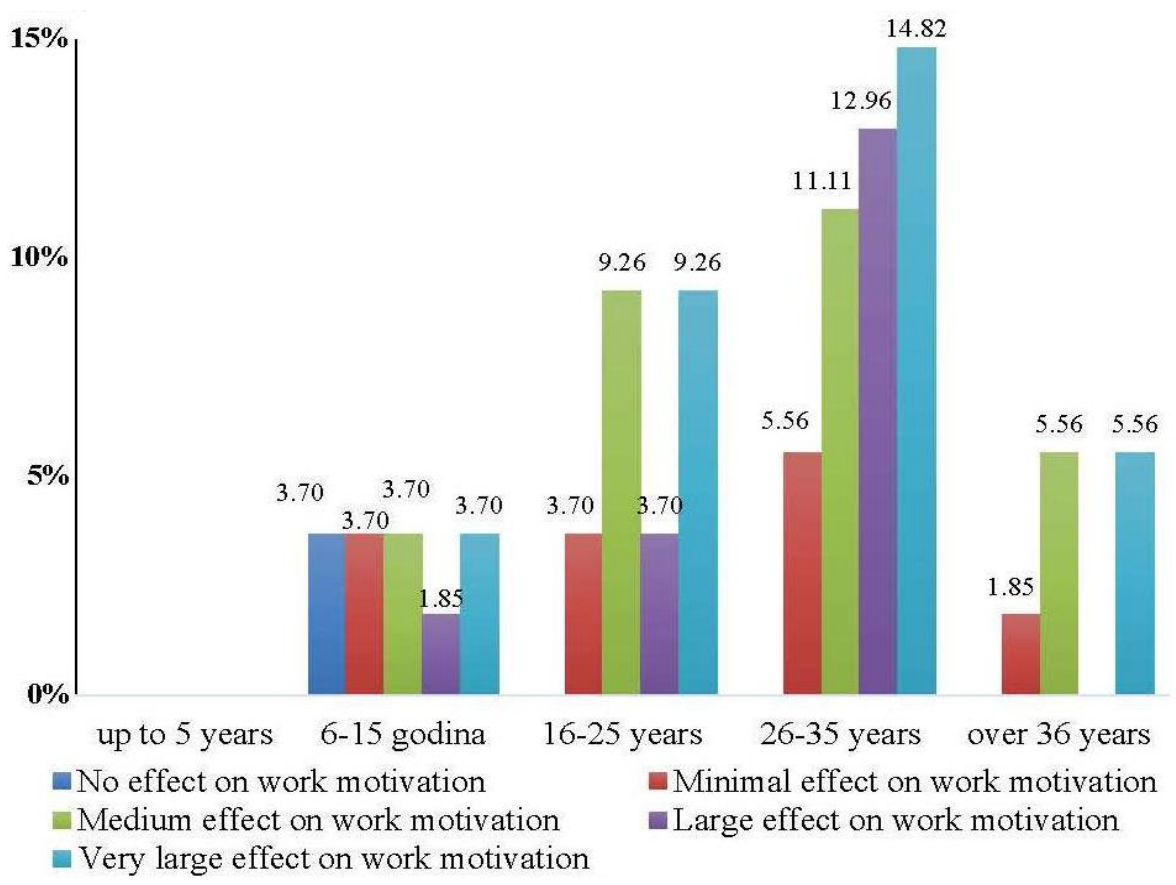

Fig. 4 The relation of motivation and years of service

\subsection{The relation of occupational safety motivation and professional competences of the examinees}

\section{- $K T G T$}

On the basis of the results obtained, it can be concluded that occupational safety motivation is significant for all employees, regardless of their degree of vocational education, which was completely predictable (Figure 5).

By detailed analysis of the obtained results, it can be concluded:

An unqualified work force is rarely motivated to work safely. If we take into account the percentage of employees who do not have motivation for safe work as well, it can be concluded that the lack of education negatively influences the motivation of workers for occupational safety.

With increasing levels of education, motivation for occupational safety becomes more prominent, except in the last category with the highest level of education where there is no risk of injuries. This group of respondednts is aware of the significance of occupational safety, and also has a large effect on occupational safety motivation in the whole organization. 


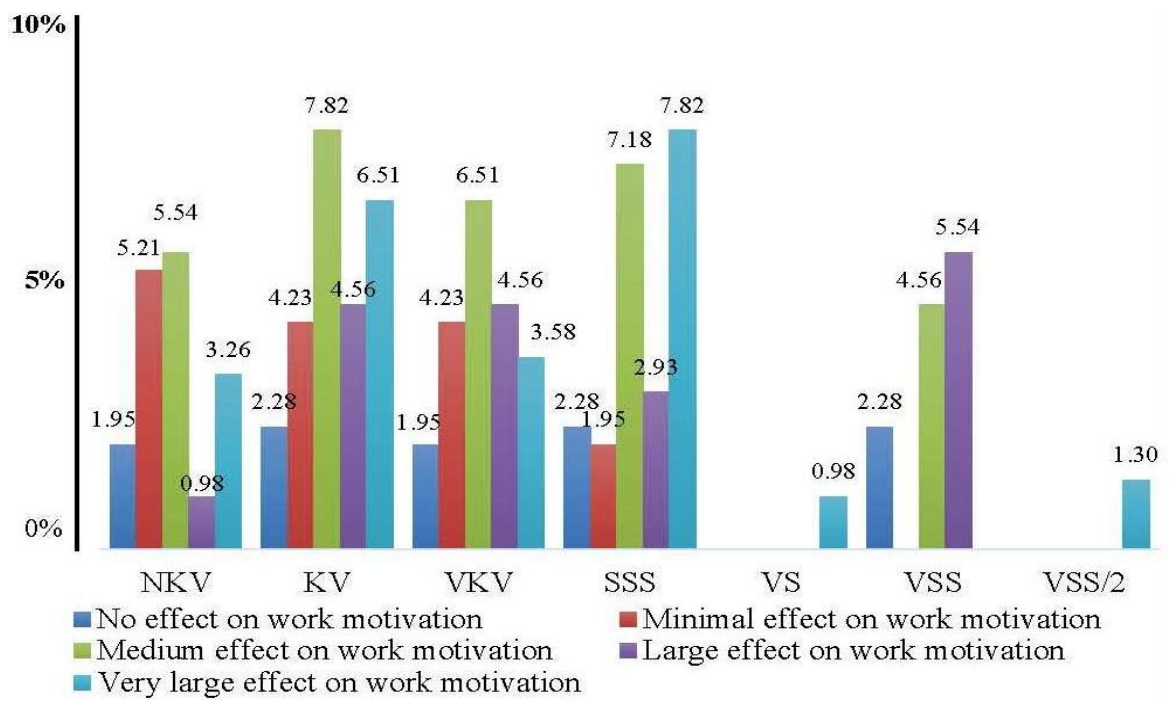

Fig. 5 The relation of motivation and professional qualifications

(Legend: NKV - unqualified workers; KV - qualified workers; VKV - highly qualified workers; SSS - secondary school qualifications; VS - two-year post-secondary school qualification; VSS - university qualifications; VSS/2 - master/PhD qualifications)

\section{- Port of Adria}

The results claim that occupational safety motivation is significant for all employees, regardless of their degree of education, which could have been predicted (Figure 6).

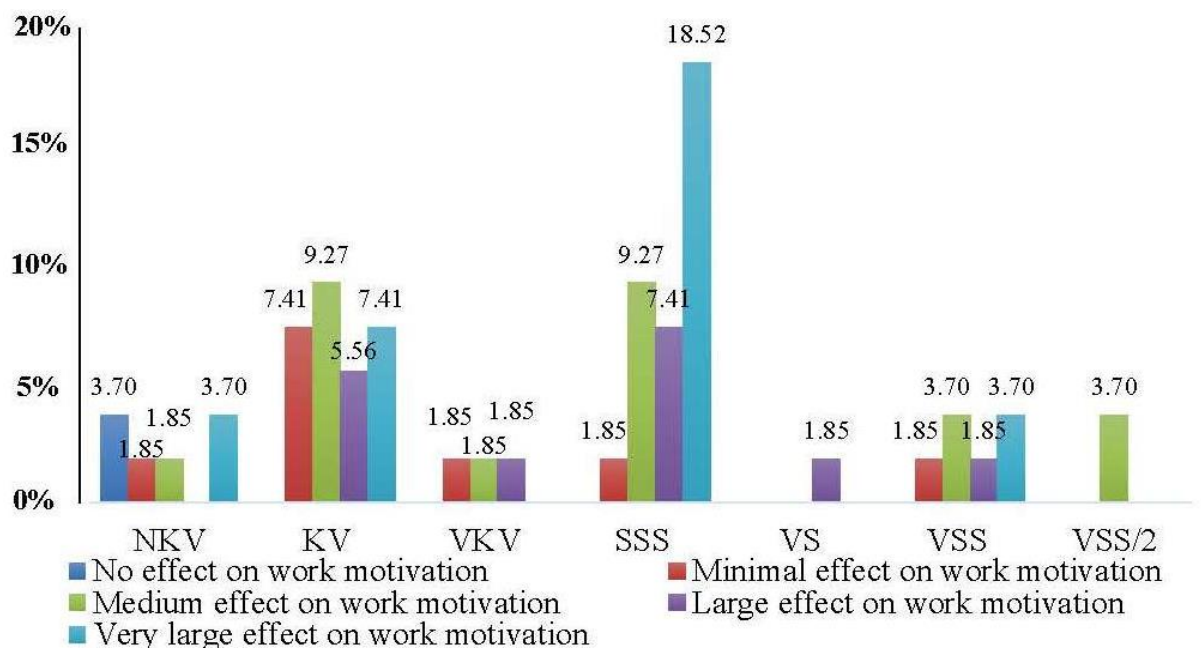

Fig. 6 The relation of motivation and degree of professional qualifications

(Legend: NKV - unqualified workers; KV - qualified workers; VKV - highly qualified workers; SSS - secondary school qualifications; VS - two-year post-secondary school qualification; VSS - university qualifications; VSS/2 - master/PhD qualifications) 
In case of an unqualified work force, there is an equal relation between large and no effect on occupational safety motivation. If the percentage of the employees with minimal effect is added to this, it can be concluded that lack of education has negative impact on occupational safety motivation among the employees.

Higher degree of education leads to a decrease of minimal and medium effect on occupational safety motivation and to an increase of affirmative attitude. For example, higher professional qualifications positively affects occupational safety motivation.

Even in the last category (management of an organization), which is risk-free from injuries it, there aren't any o negative effects and because of their education, they are aware of the significance of the occupational safety.

\section{CONCLUSION}

The examinees questioned in the company Luka Bar (KTGT), and the examinees from Port of Adria as well, aged above 50 and 41-50 have undergone different situations when it comes to work-related injuries and traumas;therefore, they have a strong attitude about the significance of occupational safety motivation.

The examinees aged 31-40 in both companies do not have clearly defined opinion on this issue, as well as the examinees aged 20-30.

Based on the above mentioned, it can be concluded that age criteria for occupational safety motivation makes clear difference in terms of age groups, and that occupational safety motivation increases with age.

The results show that the employees with more years of service (26 to 35years) and population with more than 36 years of service have a positive attitude about occupational safety, in comparison to the groups of the examinees with fewer years of service (6-15) and the group of the examinees with 16-25 years of service. For this reason, it can be concluded that occupational safety motivation is in correlation with years of service.

When it comes to education, an unqualified work force of 'KTGT' is rarely motivated to work safely. In 'Port of Adria', there is an equal relation of highly motivated individuals to work in a safe manner and those rarely motivated for safe work.

The higher degree of vocational education, the higher occupational safety motivation is, even in the last category where there is almost no risk of injury. The employees in this group are aware of the significance of occupational safety, so there is a large effect on occupational safety motivation, i.e. medium effect in that group.

The overall conclusion of this paper is that the time gap between the two surveys and the change in ownership structure did not have an effect on the occupational safety motivation correlated with age, length of service and professional qualifications of work force in 'KTGT' and 'Port of Adria'.

Acknowledgement: This research was funded by the Ministry of Education, Science and Technological Development of the Republic of Serbia. 


\section{REFERENCES}

1. Arnolds, C.A., Vender, D.J.L. (2007). The strategic importance of motivational rewards. Unpublished MBA. Nelson Mandela Metropolitan University, Port Elizabeth, SA.

2. Burney, L.L., Henle,C.A., Widener, S.K. (2009). A path model examining the relations among strategic performance measurement system characteristics, organizational justice, and extra and in-role performance. Accounting, Organizations and Society, 34(3-4), pp. 305-321.

3. Day,A. L., Sibley, A., Scott, N., Tallon, J.M., Ackroyd-Stolarz, S. (2009). Workplace risks and stressors as predictors of burnout: The moderating impact of job control and team efficacy. Canadian Journal of Administrative Sciences, 26, pp. 7-22.

4. Deci, E.L. (1971). Effects of externally mediated rewards on intrinsic motivation, Journal of Personality and Social Psychology, 18, pp. 105-115.

5. Deci, E.L., Ryan, R.M. (2000). The "What" and "Why" of goal pursuits: Human needs and the selfdetermination of behavior, Psychological Inquiry, 11, pp. 227-268.

6. Gagné, M., Deci, E.L. (2005). Self-determination theory and work motivation, Journal of Organizational Behavior, 26, pp. 331-362.

7. Judge,T.A., Illies, R. (2004). Affect and Job Satisfaction: A study of their relationship at work at home, Journal of Applied Psychology, 89, pp. 661-673.

8. Kotter, J. (2001). What leaders really do. Harvard Business School Press, Boston.

9. Rakić, T. (2018.) Motivacija za bezbednost i zdravlje na radu kao element upravljanja profesionalnim rizikom. Fakultet zaštite na radu u Nišu.

10. Ryan, R.M., Deci, E.L. (2000). Intrinsic and extrinsic motivations: classic definitions and new directions, Contemporary Educational Psychology, 25, pp. 54-67.

11. Tissan, R., Andriesen, A., Depre, F.L. (2006). Dividenda znanja. Adižes, Novi Sad.

12. Živković, S. (2008). Motivacija za zaštitu na radu, Fakultet zaštite na radu u Nišu.

13. Yusoff, F.W., Kian, T.S., Idris, T.M. (2013). Herzberg's two factors theory on work motivation: does its work for todays environment?, Global Journal of Commerce and Management Perspective, 2(5), pp. 18-22.

14. Wright, T.A. (2010). Much more than meets the eye: The role of psychological well-being in job performance, employee retention and cardiovascular health. Organizational Dynamics, 39, pp. 13-23.

\section{POVEZANOST MOTIVACIJE ZA ZAŠTITU NA RADU I STAROSTI, DUŽINE RADNOG STAŽA I STRUČNE SPREME UPOŠLJENIKA}

Autonomna motivacija za zaštitu na radu može rezultirati iz spoljašnjih i unutrašnjih razloga za primenu zaštitnih mera tokom rada. Zaposleni koji su autonomno motivisani za primenu zaštitnih mera samoinicijativno i samostalno ih primenjuju jer ih smatraju usklađenim sa njihovim ličnim vrednostima i interesima. Kao rezultat, ponašanje autonomno motivisanih zaposlenih je usmereno i određeno od strane same individue i prema tome, trebalo bi da se dosledno primenjuje.

Kod ovog tipa motivacije, treba pomenuti i identifikovanu motivaciju za zaštitu na radu koja je svojstvena zaposlenima koji su motivisani da se uključe i primenjuju mere zaštite na radu jer smatraju da je bezbedna radna sredina važna i prihvataju da je pridržavanje zaštitnih mera neophodno da bi postigli svoj cilj - bezbedno radno okruženje.

Glavni cilj ovog rada je utvrđivanje potencijalne povezanosti između motivacije za zaštitu na radu i starosne dobi ispitanika, povezanosti motivacije za zaštitu na radu i dužine radnog staža ispitanika, kao i povezanost motivacije za zaštitu na radu i stručne spreme ispitanika, sa svrhom implementacije dobijenih rezultata radi postizanja bezbednog radnog okruženja a samim tim $i$ povećanja produktivnosti.

Ključne reči: motivacija za zaštitu na radu, produktivnost, korelacija, starost, dužina radnog staža, stručna sprema 